\title{
Band migration in a patient after vertical banded gastroplasty
}

\author{
Migracja opaski u pacjentki po pionowej plastyce żołądka
}

\author{
Grzegorz Naprawa, Joanna Białkowska \\ Department of Internal Medicine, Specialistic Hospital, Szczecin Zdunowo, Poland
}

Prz Gastroenterol 2013; 8 (2): 142-145

DOI: $10.5114 /$ pg.2013.34842

Key words: migration of gastric band, vertical banded gastroplasty, bariatric surgery.

Słowa kluczowe: migracja opaski, pionowa plastyka żołądka, chirurgia bariatryczna.

Address for correspondence: Grzegorz Naprawa MD, Department of Internal Medicine, Specialistic Hospital, 11 Sokołowskiego St, 70-891 Szczecin, Poland, phone/fax: +48 9144273 69, e-mail: grzen@op.pl

\begin{abstract}
Obesity is an epidemic of the $21^{\text {st }}$ century. Complex conservative treatment is appropriate management of it. Lack of a permanent outcome and the yo-yo phenomenon make bariatric surgery the only chance for morbid obesity patients. At present, surgeons have a large range of procedures for obesity treatment. The decision which type of bariatric surgery to choose depends on the patient's condition, feeding habits, body mass and the surgeon's experience. Vertical banded gastroplasty is one of the most often used minimally invasive approaches. But no invasive treatment is free from complications. Intragastric band migration is a late mechanical complication of gastric banding. The paper describes a case of a 30-year-old woman with intragastric band migration, 4 years after vertical banded gastroplasty. Diagnosis was made with gastroscopy. To diagnose complications the endoscopist should be familiar with surgical procedures for obesity treatment.
\end{abstract}

\section{Introduction}

In 1998 the World Health Organization announced obesity to be the epidemic of the $21^{\text {st }}$ century. Its prevalence in Europe is estimated to be $10-30 \%$ in women and $10-25 \%$ in men [1], while in Poland it is $20.2 \%$ in women and $20.6 \%$ in men [2]. Obesity is a chronic disease because of its health, societal, economic and psychological consequences. It leads to shortening of life expectancy by 5 to 20 years in comparison to the population of people with correct weight [3]. Bariatric surgery emerged in the 1950s as a result of lack of satisfacto-

\section{Streszczenie}

Otyłość to epidemia XXI wieku. Podstawą jej terapii jest kompleksowe leczenie zachowawcze. Brak zadowalających wyników oraz efekt jo-jo powodują, że jedynym wyjściem dla chorobliwie otyłych pacjentów okazuje się postępowanie inwazyjne. Obecnie w chirurgii stosuje się wiele metod leczenia otyłości. Wybór rodzaju zabiegu zależy od doświadczenia chirurga, stanu ogólnego pacjenta, jego nawyków żywieniowych oraz największej masy ciała. Pionowa plastyka żołądka jest obecnie jednym z częściej wykonywanych zabiegów bariatrycznych i stosunkowo mało inwazyjnym. Każde postępowanie chirurgiczne obciążone jest ryzykiem wystąpienia powikłań. Jednym z późnych powikłań operacyjnego leczenia otyłości z zastosowaniem opaski jest jej przemieszczenie. W niniejszej pracy przedstawiono przypadek wewnątrzżołądkowej migracji opaski u 30-letniej kobiety 4 lata po pionowej plastyce żołądka. Rozpoznanie ustalono na podstawie panendoskopii. Jedynie znajomość technik operacyjnych i potencjalnych powikłań chirurgii bariatrycznej umożliwia endoskopiście postawienie właściwej diagnozy.

ry effects of conservative treatment of obesity (i.e. diet, increased physical activity, changes in life style and pharmacotherapy). Often it is the only hope for morbidly obese patients. Its efficacy in achieving and maintaining weight reduction has been proven as well as partial or complete withdrawal of numerous pathologies being its result. Simultaneously it improves quality of life and increases survival rate [4].

Surgical procedures which are meant to manage obesity can be divided into reducing food intake (restrictive), excluding part of the digestion route (malabsorptive) and mixed (restrictive-excluding). Vertical banded 
gastroplasty, which belongs to the first group, is one of the most commonly performed, relatively low invasive bariatric procedures [5]. Unfortunately, like every invasive procedure it carries the risk of complications. Migration of the gastric band into the gastric lumen is a rare complication which may occur after every bariatric surgery with the use of it. Its frequency is estimated to be $0.6-10 \%[4]$.

\section{Case report}

The 30-year-old patient was operated on because of obesity using vertical banded gastroplasty (VBG) in May 2006 in the General and Vascular Surgery Department of Specialistic Hospital in Szczecin. Indications for the procedure were a body mass index (BMI) of $49 \mathrm{~kg} / \mathrm{m}^{2}$ and previous ineffective attempts of conservative treatment. Peri- and post-operative course was without complications. In the course of 4 weeks following VBG the BMI lowered to $44 \mathrm{~kg} / \mathrm{m}^{2}$, and after the next 2 months to $39 \mathrm{~kg} / \mathrm{m}^{2}$. From August 2006 to September 2010 the patient did not attend routine visits in the Obesity Clinic. She admitted herself only in October 2010 because of non-specific abdominal pains which lasted several hours. Laboratory studies (complete blood count, C-reactive protein, urinalysis, amylase in urine and serum) and ultrasonography of abdomen performed urgently, without preparation, gave no pathological findings. The patient was scheduled to undergo panendoscopy. She admitted herself to the Endoscopy Unit, where the authors work, after 3 months, in good condition, without any symptoms. In the performed investigation, stenosis of the upper portion of the stomach (caused by surgical treatment) with a visible semicircular band fragment in its lumen was revealed (Figure $1 \mathrm{~A}, \mathrm{~B}$ ). Migration of the gastric band into the gastric lumen was diagno-

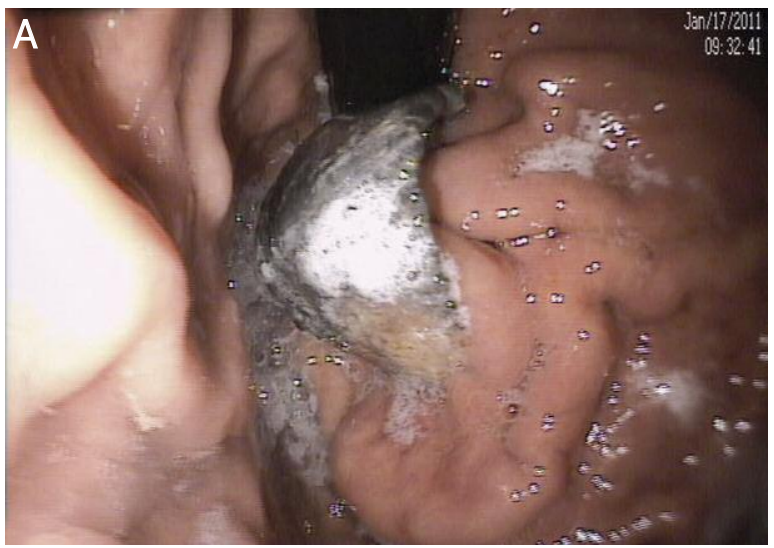

sed. The patient was again referred to the Obesity Clinic of the local hospital to determine further investigation. The patient did not give her consent to the proposed surgical treatment; she is under ambulatory observation.

\section{Discussion}

In 1998 the World Health Organization (WHO) announced obesity to be the epidemic of the $21^{\text {st }}$ century. Its prevalence in Europe is estimated to be $10-30 \%$ in women and $10-25 \%$ in men [1], in Poland $20.2 \%$ in women and $20.6 \%$ in men [2]. Obesity is a chronic disease because of its health, societal, economic and psychological consequences. It is defined as excessive fat tissue accumulation. For practical measures we use a BMI in diagnosing obesity.

According to the WHO classification a $\mathrm{BMI}$ of 18.5 $24.9 \mathrm{~kg} / \mathrm{m}^{2}$ is considered normal, a BMl of $25-29.9 \mathrm{~kg} / \mathrm{m}^{2}$ is overweight and a BMI greater than or equal to $30 \mathrm{~kg} / \mathrm{m}^{2}$ is obesity (first degree: BMI $30.0-34.9 \mathrm{~kg} / \mathrm{m}^{2}$, second degree: BMI 35.0-39.9 kg/m², third degree: BMI $\geq 40 \mathrm{~kg} / \mathrm{m}^{2}$ ). According to the European department of WHO as much as $8 \%$ of the healthcare budget is being consumed by the costs of treating obesity complications [6], which are: type 2 diabetes mellitus, cardiovascular diseases, arterial hypertension, dyslipidemia, osteoarthritis, hormonal disturbances, infertility, sleep apnea, ventilation disturbances, urine incontinence, cancers (breast, endometrium, ovary, colon) [7] and others. Obesity leads to shortening of life expectancy by 5-20 years in comparison to the population of people with correct weight [3]. It is estimated that in the European Union 1 in 13 deaths yearly is caused by excessive weight [1].

Complex conservative treatment is a foundation of obesity management to obtain negative energy balance

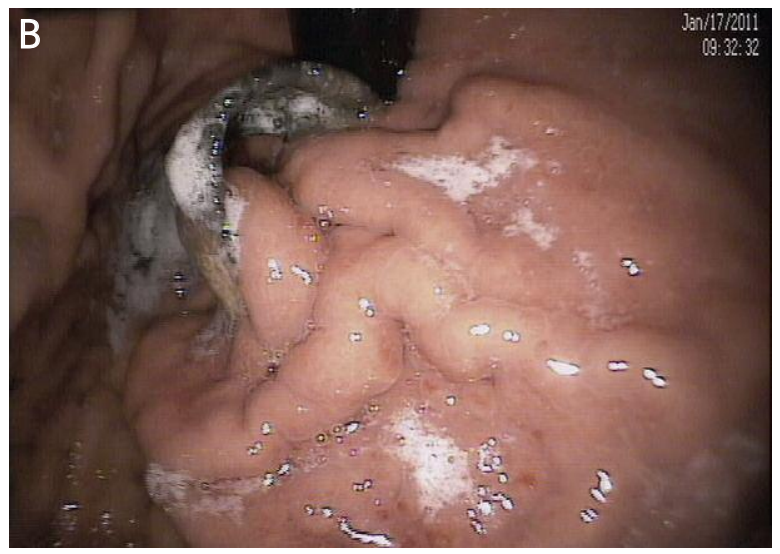

Fig. 1 A, B. Narrowing of upper part of stomach body (due to surgery) with a semicircular piece of band visible in it

Ryc. 1 A, B. Przewężenie górnej części trzonu żołądka (wywołane leczeniem operacyjnym) z widocznym pótokragtym fragmentem opaski $w$ jego świetle 
by dietary recommendations, increased physical activity, changes in life style and pharmacotherapy [1]. Regular physical exercise combined with diet is necessary for long-term maintenance of reduced weight. Conservative treatment often requires cooperation of a physician with a dietician, psychologist and physiotherapist. Pharmacotherapy is only effective when combined with dietary treatment and increased physical activity.

Bariatric surgery emerged in the 1950s as a result of lack of satisfactory effects of conservative treatment of obesity (i.e. diet, increased physical activity, changes in life style and pharmacotherapy). Often it is the only hope for morbidly obese patients. Its efficacy in achieving and maintaining weight reduction has been proven as well as partial or complete withdrawal of numerous pathologies being its result. Simultaneously it improves quality of life and increases survival rate [4].

Patients evaluated for surgical treatment of obesity are of the age of 18-60 years with a BMI equal to or greater than $40 \mathrm{~kg} / \mathrm{m}^{2}$ or $35 \mathrm{~kg} / \mathrm{m}^{2}$ with coexisting illnesses [8]. Mentioned BMI scores apply to those currently observed or documented in the past [8]. Individual indications should be considered for patients over 60 years old [8]. For children and adolescents surgical treatment should be considered at a BMI equal to or greater than $40 \mathrm{~kg} / \mathrm{m}^{2}$ with at least one coexisting disease [8]. Before deciding on surgical treatment, a patient under 18 years should undergo conservative treatment in a specialized center for at least 6 months, undergo medical and psychological evaluation before and after surgery, and prove skeletal and developmental maturity [8]. Contraindications to bariatric procedures are lack of specific healthcare and lack of opportunity to participate in the long-term post-operative assessment [8]. Surgical treatment of obesity is not indicated for people with psychiatric disorders, i.e. personality disorder, severe depression, abusing alcohol, addicted to drugs or medicines, and with illnesses which are life threatening in the short course [8].

The first bariatric surgery worldwide was performed in the 1950s. In Poland it was first performed in the 1970s - a jejuno-ileal bypass [9]. Surgical procedures which are meant to manage obesity can be divided into reducing food intake (restrictive), excluding part of the digestion route (malabsorptive) and mixed (restrictiveexcluding) [5]. The first group includes: stomach stapling or vertical banded gastroplasty (VBG), laparoscopic adjustable gastric banding (LAGB), gastric banding (GB currently very rarely performed) and sleeve gastrectomy (SG, surgical removal of a large portion of the stomach, along the lesser curvature) [5]. The second group includes bilio-pancreatic diversion (BPD) and duodenal switch [5]. The third group includes Roux-en-Y gastric bypass (RYGB) [5]. The method of treatment depends on the surgeon's experience, general condition of the patient, their eating habits and highest body mass. Proper selection of the surgery method should provide the patient with the greatest loss of weight with concurrent minimal procedure risk.

In bariatric surgery, as in every surgical procedure, complications may occur. Early side effects include, inter alia, cardiac arrest as a result of apnea, atelectasis, anastomosis leak, gastrointestinal bleeding, gastrointestinal obstruction, internal hernia, acute stomach dilatation and crush syndrome. Late postoperative complications include stenosis of gastrointestinal anastomosis, marginal ulcerations, postoperative hernia, Wernicke's encephalopathy, peripheral neuropathy, protein and caloric malnutrition, metabolic bone disease, microelement deficiency, cholelithiasis and choledocholithiasis, and lack of weight reduction effect, which applies to $10 \%$ of patients [3]. The mortality rate of bariatric surgery is estimated to be $0.1-1 \%$ depending on the applied method [10]. Fatalities occur 3-5 times less commonly in comparison to patients treated conservatively, the most rarely following gastric banding. Pulmonary embolism is the most common cause of death (0.5-1\%) [3].

Vertical banded gastroplasty is relatively low invasive and is currently one of the most commonly performed bariatric procedures [5]. It was introduced as an open method by Mason and Printen in 1971, originally as horizontal gastroplasty, changed to vertical in 1979 [5]. In 1990 McLean performed it laparoscopically using an endostapler for the first time [5]. In Poland it was first applied by Prof. Pardela in 1993 [9]. Vertical banded gastroplasty reduces the functional capacity of the stomach. Its objective is reduction of solid food intake. It involves creating a small pouch in the proximal portion of the stomach and applying a band around the outlet. A pouch of a capacity of $15 \mathrm{ml}$ is created along the lesser curvature by stapling the angle of His partition. The outlet to the remaining distal stomach portion is stabilized by a circular silicone, polypropylene, polytetrafluoroethylene or Gore-Tex band $5 \mathrm{~cm}$ in length. Ideally, the outlet canal is $11 \mathrm{~mm}$ in width and $15 \mathrm{~mm}$ in length.

The maximum weight reduction is achieved after biliopancreatic diversion (BPD), the minimum after an adjustable gastric band. Unfortunately, despite BPD's effectiveness in obesity treatment, it is characterized by the highest rate of peri- and postoperative complications (i.e. anastomosis and mechanical suture line leak) [5].

Vertical banded gastroplasty provides effective weight reduction after surgery (EWL - excess weight loss, defined as percentage of overweight loss, equals $55-65 \%)$. However, VBG is not a risk-free procedure. The 
late complication rate, reported in world literature, is estimated to be $6-26 \%$ [4]. It includes: occlusion of stomach canal with morsel, stenosis or occlusion of created stomach canal, rupture of stomach division with possible creation of gastro-gastric fistula, gastroesophageal reflux, enlargement of esophagus diameter or created pouch, restriction intolerance, hyperemesis, dysphagia, gastrointestinal hemorrhage, and migration of the band to the gastric lumen, small intestine, colon or outside the gastrointestinal tract, e.g. kidney [4].

Migration of the gastric band into the gastric lumen is a rare complication which may occur after every bariatric surgery with the use of it. Its frequency is estimated to be $0.6-10 \%$ [4]. It most commonly occurs in the first 2 years following the performed surgery. Two forms have been determined: early and late. The first is explained by minor damage of the gastric wall during the primary surgery leading to the development of severe infection. The latter (late) is justified by excessive pressure applied to the gastric wall, both from the outside and inside, leading to ischemia and necrosis of the stomach and/or polypropylene band systemic intolerance. The course of this complication is often asymptomatic or the symptoms are poorly expressed (non-specific abdominal pain, hyperemesis, weight gain, various degrees of infection severity).

Diagnosis of band migration is based on imaging studies. Early diagnosis can be determined by contrast examination of the upper gastrointestinal tract. It reveals lack of characteristic stenosis connecting the upper and lower gastric portion. It is usually confirmed in panendoscopy. It may reveal partial or complete band penetration into the gastric lumen, predominantly in the area of the fundus or anterior wall. Computed tomography of the abdomen is used primarily as a complementary test to select the treatment method [11].

The procedure of choice in the event of band migration is its removal. There are no clear guidelines for the management of time and method of implementation of this procedure.

It is proposed not to remove the band immediately in asymptomatic patients. World literature reports recommend both endoscopic and surgical methods (laparoscopy, classic laparotomy) [12]. It is believed that an attempt of endoscopic removal can be carried out if the band migration is not accompanied by other complications [4]. Reoperation is technically more difficult to perform because of scarring, primarily in the area of the cardia [4]. It is associated with a higher mortality rate in comparison to the original procedure [4]. It is believed that simultaneous removal of the migrated band, stomach repair and application of the new band can be performed in patients who do not present features of infec- tion [4]. Conversion to excluding procedures is possible, i.e. Roux-en-Y gastric bypass (RYGB) or biliopancreatic diversion.

In the discussion of the clinical case we would like to note that regardless of the rare occurrence of this complication, it must be taken into consideration in the differential diagnosis of non-specific abdominal complaints of patients after restrictive surgery. Correct diagnosis determines the further condition of the patient. It seems that due to the fact of possible oligosymptomatic complication course and predicted diagnostic and technical difficulties during reoperation, patients should be referred to centers particularly specialized in bariatric surgery.

Progress in gastrointestinal surgery, application of new techniques and the variety of surgical procedures creates a challenge for endoscopists. Lack of acquaintance with surgical methods and post-procedure modified anatomy of the digestive tract impedes orientation and, at times, prevents its proper evaluation and detection of possible complications of applied treatment.

\section{References}

1. Zahorska-Markiewicz B. Obesity - epidemic XXI century. Prevention and conservative treatment. Post N Med 2009; 22: 494-7.

2. Biela U, Pająk A, Kaczmarczyk-Hałas K, et al. The prevalence of overweight and obesity in women and men aged 20-74 years. The result WOBASZ study. Kardiol Pol 2005; 63 (Suppl 4).

3. Gtuszek S. Early and remote consequences undesirable in surgical obesity treatment. Post N Med 2009; 22: 514-23.

4. Póvoa AA, Soares C, Esteves J, et al. Simultaneous gastric and colic laparoscopic adjustable gastric band migration. Complication of bariatric surgery. Obes Surg 2010; 20: 796-800.

5. Stanowski E, Paśnik K. Bariatric surgery - the current stage of knowledge. Videosurgery Miniinv 2008; 3: 71-86.

6. Balsiger BM, Ernst D, Giachino D, et al. Prospective evaluation and 7-year follow-up of Swedish adjustable gastric banding in adults with extreme obesity. J Gastrointest Surg 2007; 11: 1470-7.

7. Dąbrowicki S. The selection of patients with morbid obesity to surgical treatment. Post N Med 2009; 22: 502-5.

8. Martin Fred M, Hainer V, Basdevantc A, et al. Interdisciplinary European Guidelines on Surgery of Severe Obesity. Post N Med 2009; 22: 554-62.

9. Stanowski E, Wyleżoł M. Development of surgical treatment of obesity In the world and In Poland. Post N Med 2009; 22: 498-501.

10. Michalik M, Stanowski E. Outcome of surgical treatment of morbid obesity. Post N Med 2009; 22: 539-44.

11. Priola AM, Priola SM, Cataldi A, et al. A case of epigastric pain in the ED: late mechanical complication after vertical banded gastroplasty. Am J Emerg Med 2009; 27: 5-7.

12. Wyleżoł $M$, Sitkiewicz $T$, Gluck $M$, et al. Intra-abdominal abscess in the course of intragastric migration of an adjustable gastric band: a potentially life-threatening complication. Obes Surg 2006; 16: 102-4. 